IBT Journal of Business Studies (IBT-JBS)

E-ISSN: 2409-6520; P-ISSN: 2414-8393

Volume 16:, 193-210 (2020)

DOI: 10.46745/ILMA.jbs.2020.161.01

\title{
Enhancing Organizational Performance through Social Media use and Knowledge Management
}

Received: 2-Jan-2019 | Accepted: 16-Jul-2020

\author{
Khawaja Khalid Mehmood $^{1 *}$ iD | Nadeem Ahmed Sheikh² iD |
}

Farkhandah Batool $^{3}$

\begin{abstract}
Researchers acknowledge the importance of knowledge, innovation, social capital, and social media for organizations. Based on practical and academic importance of these variables, hypotheses were developed and relationships have been tested among knowledge management, innovation and performance for various contexts. Furthermore, hypotheses have also been drawn to test the relationships amongst knowledge management, social capital, and social media use. However, limited research examined relationships amongst all these constructs in the same research framework, and this research attempted to cover that gap. Thus, this research pays original contribution in the form of testing an extended model regarding the impact of social media use on companies' performance involving the investigation of serial mediating effect of social capital, knowledge management, and innovation. Pakistan's home appliance industry markets around 2500 electronic products and has 95\% share domestically. Further, innovation and knowledge sharing are critical success factors for home appliance industry Therefore, this study was conducted for this industry and used survey method which resulted in 150 responses from the managers. The study finds that commercial social media's use by companies impacts knowledge management through social capital; and a serial mediating impact of these constructs exists amongst social media use and organization performance. There are extremely limited studies for electronic companies in Pakistan given the concerned variables. Therefore they are helpful for the managers concerned as these findings suggest effective use of social media by electronic companies in particular to create better organizational knowledge and improve company performance.campaigns motivate citizens to pay for safe drinking water.
\end{abstract}

Keywords: innovation, knowledge management, social capital, social media use, organizational performance, electronics industry.

JEL Classification: $L 25, P 17, P 47, M 12,032$

\section{Author's Affiliation:}

Institution:

Country:

Corresponding Author's Email:
Bahauddin Zakariya University ${ }^{1,2,3}$

Pakistan

*khawjakhalid@bzu.edu.pk

The material presented by the author(s) does not necessarily portray the view point of the editors and the management of the ILMA University, Pakistan.

2409-6520 (Online) 2414-8393 (Print) (C2020, published by the ILMA University, Pakistan.

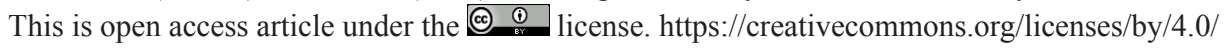

Page | 193 


\section{1) INTRODUCTION}

In order to become competent and sustainable, it is necessary to develop, acquire, and utilize knowledge efficiently and effectively (Schiuma, 2009; Schiuma, Lerro, \& Sanitate, 2008). Knowledge management-KM has made it possible for organizations to be more innovative and enhance their performance (Carmeli \& Tishler, 2004; Schiuma, De Pablos, \& Spender, 2007). Similarly, it is generally believed that innovation positively affects organization performance (Damanpour, Walker, \& Avellaneda, 2009). In high tech industries, innovation could prominently help organizations gain strong competitive advantages, as it defines ability of an organization to espouse latest ideas, present novel products (Hurley \& Hult, 1998), or to create new business models (Calantone, Cavusgil, \& Zhao, 2002) that could be point of brand preference among customers of high tech products. However, given the dynamic nature of competition, high hostility in industries, and application of modern management methods, it is admitted that several internal and external factors stand responsible for an organization's performance. Specifically, there are numerous pathways and assumptions to be met for instilling innovation and creating organizational knowledge. Among those, one of the recent tools and sources of knowledge is social media (Appel, Grewal, Hadi, \& Stephen, 2020; Vuori \& Okkonen, 2012). Social media improves interaction and communication within and across the companies (Hanna, Rohm, \& Crittenden, 2011) which positively affect organizations' social capital-SC (Zhao, 2006) as well as improve performance while minimizing costs (Kwok \& Yu, 2013). This research draws on resource based view (Penrose, 1959), knowledge based view (Gomes \& Romão, 2019), and innovation diffusion theory (Rogers, 2003) to test innovation's mediating effect for knowledge management and performance relationship. Further, it refers to social capital theory (Claridge, 2020; Lin, Ensel, \& Vaughn, 1981) and social networking theory (Barnes, $1954)$ to test mediating effect of social capital amongst social media use- SMU and KM. Importantly, limited studies have accomplished these research objectives in one research framework. Hence, this research fills important research gap of testing serial mediation impact of SC, KM, and innovation amongst SMU and organization performance.

This study selected home appliance (electronics) industry of Pakistan due to the importance, maturity, and the relevance of variables to the industry. Social media is actually becoming a necessary factor for every organization trying to achieve competitive position in both, the traditional and digital marketplace (Bosari, 2012). Home appliance sector is not an exception. Similarly, knowledge management and innovation are considered important management practices and outcomes for organizations today. The importance of innovation could even be higher for home appliance industry where it is normally considered as critical success factor (Cheng \& Shiu, 2008). Pakistan's home appliance industry is thriving and has already attained maturity. It contains greater than 95\% market share in the home market and a large pool of low cost labor; while it has also attained a number of basic technologies; and the organized sector of domestic appliances possesses adequate managerial capacity for handling export business (Kazmi, 2012). It is believed that around 2000 to 2500 electronic products are marketed in the country wherein, television has reached around $80 \%$ of households and $60 \%$ homes are estimated to 
have refrigerators and washing machines (Subohi, 2015). Further, high growth has been recorded in terms of deep freezers, air conditioners, storage batteries, electric motors, and refrigerators. However, certain segments face problems regarding disinformation about potential export markets and low quality standards. Further, the industry has been facing numerous challenges at the same time, concerning electricity load shedding, inflation, currency deflation, smuggling, and rising cost of production (Kazmi, 2012). The findings of this study are supposed to guide practicing managers in this industry to help improve their companies' performance.

\section{0) LITERATURE REVIEW}

The following subsections present critical review of literature on the concerned variables. The study was basically initiated and the research framework was drawn based on systematic review of the literature. That included search of relevant papers from multiple sources including Emerald, Science Direct, JSTOR, and Google Scholar. This search resulted in more than 150 papers. Both conceptual/ review papers and empirical research papers published until 2019 covering either qualitative or quantitative methodologies were included. This study, however constructed its research framework on the basis of majorly quantitative studies.

\section{1)KNOWLEDGEMANAGEMENT,INNOVATION,\&ORGANIZATIONAL PERFORMANCE}

Knowledge management covers variety of activities like creation, acquisition, sharing, capturing, disseminating, and applying knowledge effectively to improve organization performance (Fernandez \& Sabherwal, 2010). Knowledge management is explained through resource based view (Penrose, 1959) which argues that organizations need to focus on management of their tangible and intangible resources that need to be acquired as well as utilized properly for organization's success. It is further elaborated by knowledge based view (Gomes \& Romão, 2019) which presents knowledge as a primary source for value creation and a basis to get competitive advantage. Scholars have reported that organizations with better knowledge management have greater chances to get superior and sustainable performance (Darroch, 2005; Mohammad \& Roozbeh, 2014). For instance, study of Mohammad and Roozbeh (2014), covering multiple sectors in North America reported significant knowledge management's impact on performance.

Furthermore, it has been argued that knowledge management supports innovation (Cavusgil, Calantone, \& Zhao, 2003; Hussain, Qurashi, Mujtaba, Waseem, \& Iqbal, 2019). In context of innovation diffusion theory, when innovation is adopted by individuals, it indicates foundation as well as diffusion of innovation (Rogers, 2003). Effective knowledge management supports the process of innovation process as it produces right information needed to create right type of innovation. It provides the basis, ability, and organizational capacity to become more innovative and be more successful (Carmeli \& Tishler, 2004; Schiuma et al., 2007). One the other hand, scholars have argued that in many contexts, innovation determines organization's ability to improve its performance (Damanpour et al., 2009; Mehmood, Sonia, \& Umar, 2016). These arguments provide support for testing 
IBT JOURNAL OF BUSINESS STUDIES (IBT-JBS) Volume 16 Issue 1, 2020

innovation as an intervening variable amongst $\mathrm{KM}$ and performance. This role has also been supported by research of Taherparvar, Esmaeilpour, and Dostar (2014) in context of Iranian banks. Therefore, following hypotheses are developed:

H1. Knowledge management significantly impacts organizational performance.

$\mathrm{H} 2$. Knowledge management significantly impacts innovation.

H3. Innovation significantly impacts organizational performance.

H4: Knowledge management impacts organizational performance through innovation.

\section{2) USE OF SOCIAL MEDIA, GENERATION OF SOCIAL CAPITAL AND ORGANIZATIONAL KNOWLEDGE.}

Social media enables individuals to share information and interact with others on social networking sites using wide approachability and ascendable transmission techniques on internet (Khaniki, 2011). Today, social media has gained various types such as social networking sites like Myspace, twitter, Facebook; as well as blogs, social news, book marking sites; and media sharing sites such as YouTube \& flicker (Lee, 2013). Social media plays a critical role in increasing the intention of technology adoption and innovation diffusion (Ainin, Parveen, Moghavvemi, Jaafar, \& Shuib, 2015). Importantly, social media use promotes knowledge management activities while providing several opportunities for companies to share, acquire, and distribute information and knowledge (Helms, Cranefield, \& van Reijsen, 2017; Vuori \& Okkonen, 2012) and to increase interaction with customers and other stakeholders (Berthon, Pitt, Plangger, \& Shapiro, 2012; Mangold \& Faulds, 2009). This could promote innovation (Jussila, Kärkkäinen, \& Leino, 2012; Standing \& Kiniti, 2011). Scholars believe that social media has encouraged organizations towards trying out new ways of interaction and communication in order to create and extract new information from inside and outside sources (Hanna et al., 2011).

Furthermore, it has been believed that social media use leads towards creation of social capital (Zhao, 2006). SC theory explains social capital and it emphasizes on people's capacity to benefits from their interpersonal relations and membership in social organizations, as well as from their social structure (Fu, 2004). Social networking theory explains social capital as something originating from social interactions and relations which are expressed through nodes (actors within networks) and ties (relationships/interactions between those actors) (Barnes, 1954; Han, Chae, Passmore, 2019). It is further argued that social capital affects flow of knowledge or information in an organization (Adler \& Kwon, 2002; Monavvarian, Asgari, Akhavan, \& Ashena, 2013) and determines success of knowledge management programs. Research by Bharati, Zhang, and Chaudhury (2015) in context of U.S. affirmed this viewpoint and reported social media as a predictor for firm emphasis on social capital and the process of knowledge management. Hence, following hypotheses are developed in the light of above discussion. The construct social media used in this research basically points towards social media use or adoption for the purpose of sharing valuable and organizational information.

H5. Social media use significantly impacts knowledge management. 
H6. Social media use significantly impacts social capital.

H7. Social capital significantly impacts knowledge management.

$\mathrm{H} 8$ : The use of social media in organizations help manage organizational knowledge through building adequate social capital.

\section{3) THE CASE OF SERIAL MEDIATION BETWEEN SOCIAL MEDIA USE \& ORGANIZATIONAL PERFORMANCE.}

Internet has made it possible for organizations to engage with their stakeholders through social media technology anywhere in the world. As argued earlier, social media has decreased the barriers of communication as well as operational costs by providing a direct link to various stakeholders particularly customers (Hanna et al., 2011). Organizations use social media for various purposes like sales, advertising, marketing, communication, innovation, and customer services (Appel et al., 2020; Bhanot, 2012). Social media has been useful in improving the sales performance of organizations by granting a direct interaction with customers and other stakeholders (Rodriguez, Peterson, \& Ajjan, 2015). Therefore, certain scholars argue that when used effectively and efficiently, social media technology positively affects organization's performance (Dodokh \& Al-Maaitah, 2019; Shuai \& Wu, 2011). Research of Ainin et al. (2015) on 259 Malaysian SMEs recently reported positive effect of social media use on financial and non-financial performance of SMEs, as it reduced customer service cost and marketing cost of SMEs, while providing them enough information to enhance customer relations. The arguments and justifications for impact of SMU on SC, impact of SC on KM, impact of KM on innovation, and finally regarding effect of innovation on organization performance have been provided earlier in the previous sections of this paper. Therefore, hypothesis H10, concerning serial mediating effect of these variables between social media use and organization performance is provided as below.

H9: Social media use significantly affects an organizational performance.

H10: SC, KM, and innovation act as serial mediators amongst SMU and organizational performance.

The theoretical framework for this research developed on the basis of the discussions made in section 1 is provided in figure 1. 


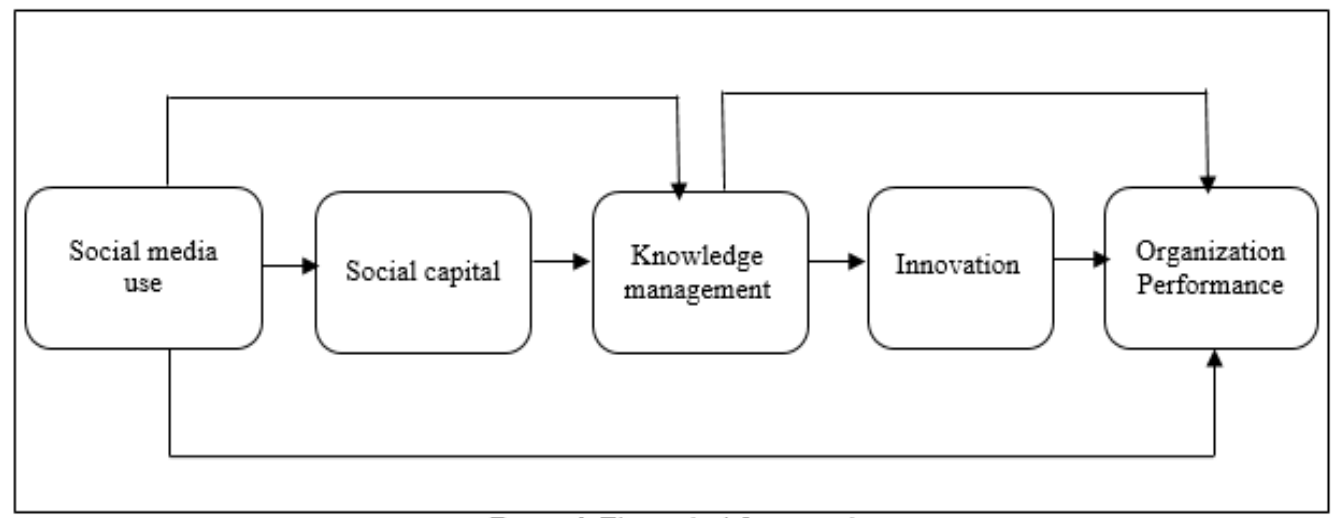

Figure 1. Theoretical framework.

\section{2) METHODOLOGY}

This study was quantitative in nature and relied on survey method to collect the data. The data was collected from electronic sector (home appliances) of Pakistan. For questionnaire (seven-point Likert type scale has been employed), all measures were borrowed through past studies. KM items were taken from study of Young (2016), SC had 3-dimensions and their items were adopted from research of Fatoki (2011), social media use items were taken from study of Wu (2016), and innovation constructs were adopted from research of Calantone et al. (2002). The measurement items for performance were borrowed through study of Felício, Couto, and Caiado (2014).

Two hundred and fifty questionnaires were sent to top/middle level managers and 150 questionnaires were responded by 17 companies (the list of the companies was developed through secondary data sources through internet). These companies were Dawlance, Enviro, Haier, Orient, Gree, Kenwood, PEL, Sony, Electrolux, Samsung, Changhong Ruba, Waves, Homage, Panatron, Westpoint, National, and EcoStar. The questionnaires were distributed in seven cities including Bhawalpur, Multan, DG Khan, Faisalabad, R.Y. Khan, Karachi, and Rawalpindi. In each city, instead of taking sample the questionnaires were distributed to all the companies. Table 1 includes detail about number of questionnaires received from each city; whereas Table 2 includes demographic information about the respondents. Outlier analysis was conducted using Mahalanobis Distance on SPSS and 16 outliers were identified. After removing them, it left with 134 questionnaires for final analyses. Among respondents, 98\% were males, $53 \%$ had ages between $26-35$ years, 36\% had ages between 36-45 years, and 56\% had a Master's degree. 
IBT JOURNAL OF BUSINESS STUDIES (IBT-JBS) Volume 16 Issue 1, 2020

Table 1. Responses from Cities

\begin{tabular}{lcc}
\hline Cities & $\begin{array}{c}\text { Questionnaires } \\
\text { obtained }\end{array}$ & Percentage \\
Multan & 14 & $9.33 \%$ \\
Rawalpindi & 20 & $13.33 \%$ \\
Bahawalpur & 30 & $20 \%$ \\
Karachi & 19 & $12.66 \%$ \\
D.G Khan & 16 & $10.66 \%$ \\
Faisalabad & 13 & $8.66 \%$ \\
Rahim Yar Khan & 38 & $25.33 \%$ \\
Total & 150 & $100 \%$ \\
\hline
\end{tabular}

Table 2. Respondent Demographics

\begin{tabular}{lclclc}
\hline Qualification & Frequency & Gender & Frequency & Age & Frequency \\
\hline Master & 75 & Female & 02 & $46-70$ & 7 \\
Bachelor & 58 & Male & 132 & $36-45$ & 48 \\
Matric & 01 & & & $26-35$ & 71 \\
& & & & $12-25$ & 8 \\
\hline
\end{tabular}

$$
(n=134)
$$

\section{3) ANALYSES AND FINDINGS}

For model testing, SmartPLS 3.0 was used as it has the ability to handle small sample sizes like the one in this research. All constructs were treated through reflective model except social capital which was treated using second order formative model.

\section{1) ASSESSMENT OF MEASUREMENT PROPERTIES}

This section discusses reliability and validity of measurement data. Statistics regarding measurement properties are provided in Table 3 . For convergent validity, it shows that all items' loadings were greater than 0.7 (Henseler, Ringle, \& Sarstedt, 2012), except for $\mathrm{O} 16$ which was 0.65 and could be retained in the analysis according to Birkinshaw, Morrison, and Hulland (1995). All four items of social media use had satisfactory loadings. For knowledge management construct, five out of eight items had satisfactory loadings. Only one item of organizational innovation was removed; and for organization performance, all the six items had satisfactory loadings. Further, convergent validity was also ensured through composite reliability as it was greater than 0.7 (Yi \& Davis, 2003). Average Variance Extracted (AVE) for all constructs was also greater than 0.5 showing convergent and divergent validity (Chin, 1998; Garson, 2016).

For discriminant validity, Fornell and Larcker (1981) criteria was used. As per criteria, every construct's square root of AVE was higher compared to that construct's Page | 199 
IBT JOURNAL OF BUSINESS STUDIES (IBT-JBS) Volume 16 Issue 1, 2020 correlations with other constructs. Moreover, HTMT (Heterotrait-Monotrait Ratio) ratios were also less than 1.0. (Garson, 2016). So, it is also fulfilling the recommended threshold. For reliability, Cronbach alpha for all variables was also acceptable as it was greater 0.7 (Hair, Babin, Money, \& Samouel, 2003). All statistics for Variance Inflation Factor (VIF) were below 4.0 and were satisfactory (Garson, 2016). Model fit was reached through SRMR of 0.074 (Hu \& Bentler, 1998).

Table 3. Validity \& Reliability

\begin{tabular}{|c|c|c|c|c|c|c|}
\hline Constructs & $\begin{array}{c}\text { Item } \\
\text { Codes }\end{array}$ & AVE & $\begin{array}{l}\text { Cronbach's } \\
\text { alpha }\end{array}$ & $\begin{array}{l}\text { Composite } \\
\text { Reliability }\end{array}$ & VIF & Loadings \\
\hline \multirow{5}{*}{ Social media use } & SM1 & & & & 3.309 & 0.91 \\
\hline & SM2 & & & & 3.509 & 0.91 \\
\hline & SM3 & & & & 2.688 & 0.86 \\
\hline & SM4 & & & & 3.162 & 0.90 \\
\hline & & 0.806 & 0.92 & 0.943 & & \\
\hline \multirow{6}{*}{$\begin{array}{l}\text { Knowledge man- } \\
\text { agement }\end{array}$} & KM1 & & & & 2.638 & 0.88 \\
\hline & KM2 & & & & 2.972 & 0.88 \\
\hline & KM3 & & & & 1.850 & 0.80 \\
\hline & KM4 & & & & 2.202 & 0.81 \\
\hline & KM5 & & & & 1.911 & 0.77 \\
\hline & & 0.68 & 0.88 & 0.915 & & \\
\hline \multirow{6}{*}{ Innovation } & OI1 & & & & 1.800 & 0.78 \\
\hline & OI2 & & & & 2.115 & 0.81 \\
\hline & $\mathrm{OI} 3$ & & & & 2.289 & 0.84 \\
\hline & OI4 & & & & 1.535 & 0.70 \\
\hline & OI6 & & & & 1.207 & 0.65 \\
\hline & & 0.57 & 0.81 & 0.869 & & \\
\hline \multirow{7}{*}{$\begin{array}{l}\text { Organization Per- } \\
\text { formance }\end{array}$} & OP1 & & & & 2.911 & 0.88 \\
\hline & OP2 & & & & 3.010 & 0.87 \\
\hline & OP3 & & & & 3.169 & 0.87 \\
\hline & OP4 & & & & 3.009 & 0.88 \\
\hline & OP5 & & & & 2.520 & 0.85 \\
\hline & OP6 & & & & 1.827 & 0.75 \\
\hline & & 0.724 & 0.92 & 0.940 & & \\
\hline
\end{tabular}




\section{2) STRUCTURAL MODEL ASSESSMENT}

The Partial Least Squares algorithm and bootstrapping were used for testing all hypotheses in the structural model. Figure 2 shows structural model and all the findings and the results of hypotheses tests are presented in table 4.

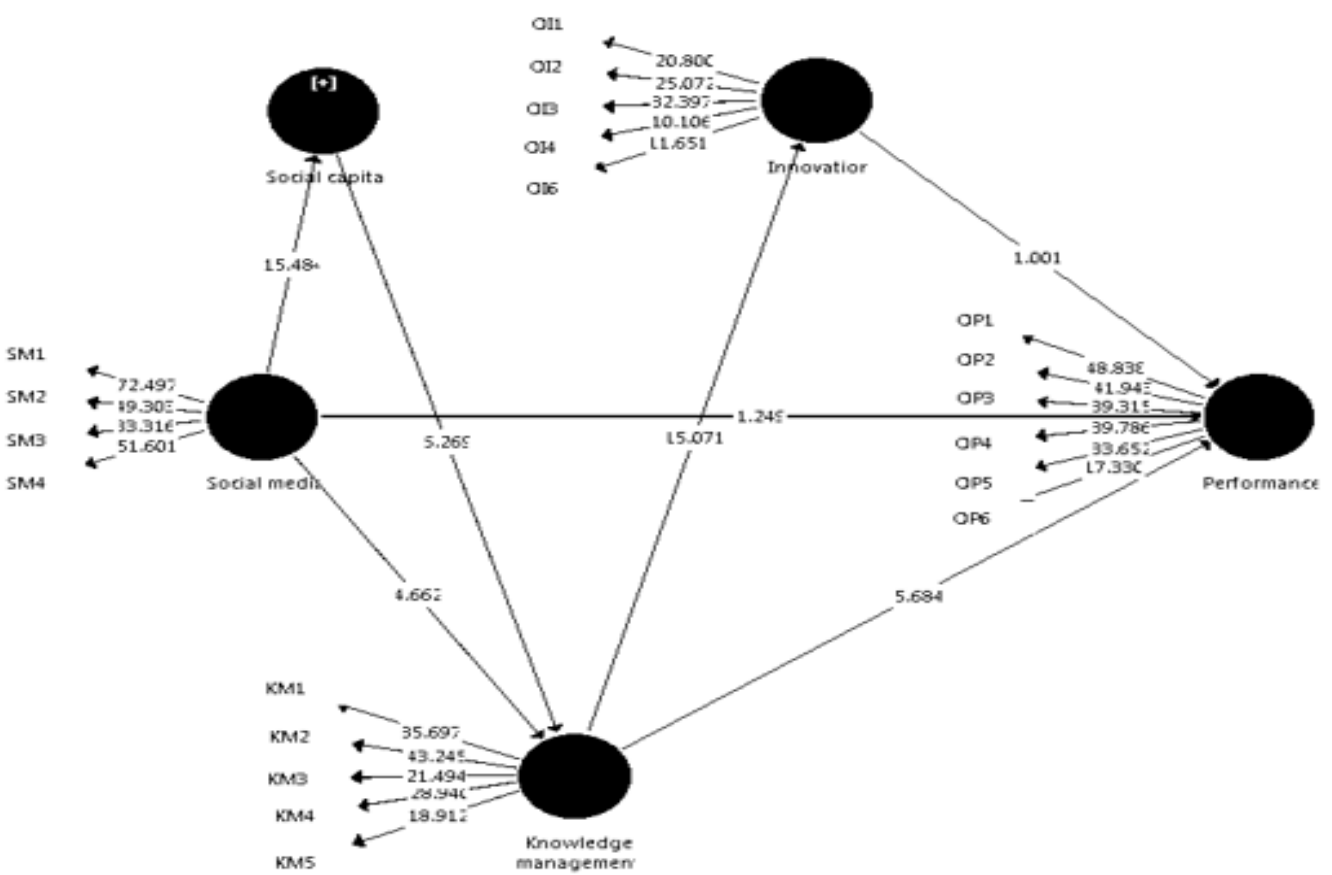

Figure 2. Structural Model

Out of ten hypotheses in this study, seven were accepted. Firstly, hypothesis 4 concerning innovation's mediating effect between knowledge management and performance was not accepted as knowledge management had insignificant indirect impact on performance (t-value: 1.043, p-value: 0.297). This hypothesis was rejected due to insignificant innovation's effect on performance (H3 also rejected). However, $\mathrm{H} 1$ and $\mathrm{H} 2$ regarding knowledge management's direct impact on performance and innovation respectively were accepted as evident through their $\mathrm{p}$-values and t-values. Positive coefficients further indicate positive nature of impact. 
IBT JOURNAL OF BUSINESS STUDIES (IBT-JBS) Volume 16 Issue 1, 2020

Table 4. Findings of the Structural Model

\begin{tabular}{|l|l|l|l|l|l|l|l|}
\hline \multirow{2}{*}{ Relations } & \multicolumn{2}{|c|}{ IndirectEffects } & \multicolumn{3}{c|}{ DirectEffects } & \multicolumn{2}{c|}{$\begin{array}{c}\text { Biased Corrected } \\
\text { Confidence } \\
\text { Interval }\end{array}$} \\
\cline { 2 - 8 } & t-values & p-values & t-values & $p$-values & $\begin{array}{c}\text { Coeffi- } \\
\text { cients }\end{array}$ & $2.5 \%$ & $97.5 \%$ \\
\hline $\begin{array}{l}\text { Knowledge management } \rightarrow \\
\text { Performance }\end{array}$ & 1.043 & 0.297 & 5.535 & 0.000 & 0.582 & 0.405 & 0.808 \\
\hline $\begin{array}{l}\text { Knowledge management } \rightarrow \\
\text { Innovation }\end{array}$ & & & 15.785 & 0.000 & 0.653 & 0.598 & 0.753 \\
\hline Innovation $\rightarrow$ Performance & & & 1.046 & 0.296 & 0.085 & -0.087 & 0.232 \\
\hline $\begin{array}{l}\text { Social media use } \rightarrow \text { Knowl- } \\
\text { edgemanagement }\end{array}$ & 5.288 & 0.000 & 4.603 & 0.000 & 0.371 & 0.208 & 0.518 \\
\hline $\begin{array}{l}\text { Social capital } \rightarrow \\
\text { Knowledgemanagement }\end{array}$ & & & 6.182 & 0.000 & 0.490 & 0.350 & 0.656 \\
\hline $\begin{array}{l}\text { Social mediause } \rightarrow \\
\text { Social capital }\end{array}$ & & & 15.826 & 0.000 & 0.717 & 0.635 & 0.813 \\
\hline $\begin{array}{l}\text { Social media use } \rightarrow \text { Perfor- } \\
\text { mance }\end{array}$ & 5.648 & 0.000 & 1.224 & 0.221 & 0.160 & -0.123 & 0.389 \\
\hline
\end{tabular}

Secondly, hypothesis H8 about SC's mediating role between SMU and KM was accepted as supported through significant indirect impact of SMU on KM (t-value: 5.288, p-value: 0.000). Since, social media use's direct impact on knowledge management was also significant (H5 accepted), so it infers that mediating effect of social capital is partial. Hypothesis $\mathrm{H} 6$ and $\mathrm{H} 7$ were also accepted and it is reported that social media use impacts social capital creation (t-value: 15.826, p-value: 0.000 ) and social capital impacts knowledge management (t-value: 6.182 , p-value: 0.000 ) in an organization. Positive coefficients further indicate positive nature of impact.

Hypothesis 10 for the serial mediation was accepted and supported through the significant indirect effect of social media use on performance (t-value: 5.648, p-value: 0.000). Further, direct impact of social media use on performance (H9) was insignificant (t-value: 1.224 , p-value: 0.221 ), therefore the findings support for the full serial mediating effect. Next section presents information about additional analysis regarding difference of opinion between respondents. 


\section{3) DEMOGRAPHIC DIFFERENCES AND IMPLICATIONS}

In order to examine difference of opinion among various categories of respondents, an additional test was conducted using Anova and t-test. As already highlighted in section 2, there was only one female respondent, therefore, t-test was not conducted for gender and while reading this study's conclusions, it should be acknowledged that the findings are largely based on the responses collected from male respondents. Anova was conducted for any significant differences of opinion between respondents of different ages and it was found that none of the differences were significant. This concludes that respondents of all age groups had similar sort of evaluation for all the variables. A large majority of respondents either had bachelor's degree (59) or a master's degree (75) and t-test was conducted to study the difference in the two groups. The results are provided in table 5 below and they reveal significant differences among groups for all variables. The groups statistics and significance levels establish that master degree holders had higher level of agreement for adoption/use of all variables in their companies including social media (mean for master degree holders $=6.14$, mean for bachelor degree holders $=$ $5.27)$, social capital $(5.95>5.34)$, knowledge management $(5.96>5.18)$, innovation $(5.97>5.64)$, and performance $(6.14>5.63)$.

Table 5. t-test results for qualification

\begin{tabular}{|c|c|c|c|c|c|}
\hline \multirow{3}{*}{ Constructs } & & \multicolumn{4}{|c|}{ t-test for Equality of Means } \\
\hline & & \multirow{2}{*}{$\mathbf{t}$} & \multirow{2}{*}{ Sig. (2-tailed) } & \multicolumn{2}{|c|}{$\begin{array}{l}\text { 95\% Confidence Inter- } \\
\text { val of the Difference }\end{array}$} \\
\hline & & & & Lower & Upper \\
\hline \multirow[t]{2}{*}{ Social Media } & 1 & -5.55 & \multirow{2}{*}{.000} & -1.17 & -.56 \\
\hline & 2 & -5.39 & & -1.18 & -.55 \\
\hline \multirow[t]{2}{*}{ Knowledge Management } & 1 & -5.93 & \multirow{2}{*}{.000} & -1.04 & -.52 \\
\hline & 2 & -5.64 & & -1.05 & -.51 \\
\hline \multirow[t]{2}{*}{ Innovation } & 1 & -3.01 & \multirow{2}{*}{.003} & -.55 & -.11 \\
\hline & 2 & -2.97 & & -.55 & -.11 \\
\hline \multirow[t]{2}{*}{ Performance } & 1 & -3.49 & \multirow{2}{*}{.001} & -.80 & -.22 \\
\hline & 2 & -3.48 & & -.80 & -.22 \\
\hline \multirow[t]{2}{*}{ Social Capital } & 1 & -5.14 & \multirow{2}{*}{.000} & -.84 & -.37 \\
\hline & 2 & -4.94 & & -.85 & -.36 \\
\hline
\end{tabular}

(1: equal variances assumed, 2: equal variances not assumed) 


\section{4) CONCLUSIONS, DISCUSSIONS, AND IMPLICATIONS}

This study has produced certain interesting results. Initially, it concludes about positive knowledge management's effect on performance $(\mathrm{H} 1)$. This finding gets support from knowledge based view, resource based view, and past researches. RBV centers on effective use and deployment of unique resources to achieve better performance (Barney, 1991) and according to KBV, knowledge is one of them(Gomes \& Romão, 2019; Schiuma, 2009; Schiuma et al., 2008). For being innovative and efficient, companies have to manage their knowledge which leads towards better performance (Carmeli \& Tishler, 2004; Hussain et al., 2019; Schiuma et al., 2007). Hypothesis H2, concerning knowledge management's effect on innovation was also accepted. It gets support of past studies as well which suggest that knowledge is a unique resource that is helpful in making decisions regarding other organizational resources as well as to get certain organizational benefits (Darroch, 2005; Penrose, 1959). When organization develops the capability not only to manage its knowledge but also to use it effectively, it ends into development of innovation (Ode \& Ayavoo, 2020). This is also consistent with innovation diffusion theory and resource based view. Innovation diffusion theory emphasizes on effective deployment of resources like knowledge management for achieving innovation (Rogers, 2003). Hypothesis $\mathrm{H} 3$ concerning impact of innovation on performance was not accepted. This was an interesting finding; however, it also gets support from certain past studies (Mehmood et al., 2016; Ndesaulwa \& Kikula, 2017). As H3 was not supported, therefore $\mathrm{H} 4$ did not get support concerning innovation's mediating effect amongst $\mathrm{KM}$ and performance. This finding gets partial support from study of Al-Sa'di, Abdallah, and Dahiyat (2017) which reported that only process innovation mediated knowledge management-performance relationship, and product innovation did not.

Furthermore, hypotheses H5, H6, H7, and H8 were accepted and the results conclude significant SC's role as a mediator between SMU and KM. These results are consistent with the findings of past researches (Baehr \& Alex-Brown, 2010; Ellison, Steinfield, \& Lampe, 2007; Gurteen, 2012; Hemsley \& Mason, 2013; Kumar \& Bhagwat, 2010; Mangold \& Faulds, 2009; Pentina, Koh, \& Le, 2012; Sabatini, 2006). Resource based view, social networking theory, and innovation diffusion theory also support these findings. Hypothesis H10 concerning serial mediating roles of SC, KM, and innovation amongst SMU and performance got accepted. Various relationships between variables for $\mathrm{H} 10$ are supported by past researches (Bughin, Byers, \& Chui, 2011; Gurteen, 2012; Hemsley \& Mason, 2013; Zhao, 2006) and by theories such as resource based view, social networking theory, and innovation diffusion theory. Previous studies show that when social media is adopted and used effectively, then organizations can get benefits in the form of quality communication, business development, competitive advantage, and social relations which may lead to improve organizational performance (Dodokh \& Al-Maaitah, 2019; Shuai \& Wu, 2011).

As highlighted earlier, research on the concerned variables in the context of electronic companies in Pakistan is extremely limited. Thus, this study has made genuine contribution in testing an extended model regarding the impact of social media use on electronic companies' performance involving the investigation of 
serial mediating effect of social capital, knowledge management, and innovation. Even in foreign contexts, scholars tested hypotheses involving limited variables. This study developed and tested extended model involving several mediators to study the impact of social media use on companies' performance. Based on the analyses performed, results reported, and discussions made, this study has validated its findings and the objectives of the study as noted earlier have been achieved. The results possess important implications for the researchers as well as managers. The results contribute towards different underpinning theories such as, resource based view, social networking theory, knowledge based view, and innovation diffusion theory. This study provides new perspective to researchers for understanding and studying the role of social media in improving organizational performance, knowledge management, and other outcomes. The study is useful for the managers particularly in Pakistan's home appliance sector to adopt social media for increasing knowledge management and enhancing performance. Specifically, managers could adopt and use social media in effective way to improve knowledge management which will lead to better organizational performance. The findings are also helpful for managers working in other companies such as automobiles, electric component manufacturers, creative marketing, and others facing similar external conditions and industry circumstances to understand the role of social media in improving social capital which further promotes knowledge management and other organizational factors.

\section{5) LIMITATIONS}

This study has some limitations. It was conducted in Pakistan only, so it has limited geographical generalizability. Survey method was used to test the framework and the limitations of the survey method could not be overlooked. The study performed only cross sectional analysis of relationships under examination. For the future research, similar topics could be studied using qualitative research methods. Data from other sectors and country contexts would surely add to the findings and body of knowledge.

\section{REFERENCES}

Adler, P.S., \& Kwon, S.W. (2002). Social capital: Prospects for a new concept. Academy of Management Review, 27(1), 17-40.

Ainin, S., Parveen, F., Moghavvemi, S., Jaafar, N.I., \& Shuib, N.L.M. (2015). Factors influencing the use of social media by SMEs and its performance outcomes. Industrial Management \& Data Systems, 115(3), 570-588.

Al-Sa'di, A.F., Abdallah,A.B., \& Dahiyat, S.E. (2017). The mediating role of product and process innovations on the relationship between knowledge management and operational performance in manufacturing companies in Jordan. Business Process Management Journal, 23(2), 349-376.

Appel, G., Grewal, L., Hadi, R., \& Stephen, A. T. (2020). The future of social media in marketing. Journal of the Academy of Marketing Science, 48(1), 79-95.

Page $\mid 205$ 
IBT JOURNAL OF BUSINESS STUDIES (IBT-JBS) Volume 16 Issue 1, 2020

Baehr, C., \& Alex-Brown, K. (2010). Assessing the value of corporate blogs: A social capital perspective. IEEE Transactions on Professional Communication, 53(4), 358-369.

Barnes, J.A. (1954). Class and committees in a Norwegian island parish. Human relations, $7(1), 39-58$.

Barney, J. (1991). Firm resources and sustained competitive advantage. Journal of Management, 17(1), 99-120.

Berthon, P.R., Pitt, L.F., Plangger, K., \& Shapiro, D. (2012). Marketing meets Web 2.0, social media, and creative consumers: Implications for international marketing strategy. Business Horizons, 55(3), 261-271.

Bhanot, S. (2012). Use of social media by companies to reach their customers. SIES Journal of Management, 8(1), 47-55.

Bharati, P., Zhang, W., \& Chaudhury, A. (2015). Better knowledge with social media? Exploring the roles of social capital and organizational knowledge management. Journal of Knowledge Management, 19(3), 456-475.

Birkinshaw, J., Morrison, A., \& Hulland, J. (1995). Structural and competitive determinants of a global integration strategy. Strategic Management Journal, 16(8), 637-655.

Bosari, J. (2012). The developing role of social media in the modern business world. Forbes, Consultado em Setembro, 27. Retrieved from www.forbes.com/ sites/moneywisewomen/2012/08/08/the-developing-role-of-social-media-inthe-modern-business-world/\#5ccc98846fd6 (accessed on October, 31, 2017).

Bughin, J., Byers, A.H., \& Chui, M. (2011). How social technologies are extending the organization. McKinsey Quarterly, 20(11), 1-10.

Calantone, R.J., Cavusgil, S.T., \& Zhao, Y. (2002). Learning orientation, firm innovation capability, and firm performance. Industrial Marketing Management, 31(6), 515-524.

Carmeli, A., \& Tishler, A. (2004). The relationships between intangible organizational elements and organizational performance. Strategic Management Journal, 25(13), 1257-1278.

Cavusgil, S.T., Calantone, R.J., \& Zhao, Y. (2003). Tacit knowledge transfer and firm innovation capability. Journal of Business \& Industrial Marketing, 18(1), $6-21$.

Cheng, C.C.J., \& Shiu, E. C. (2008). Critical success factors of new product development in Taiwan's electronics industry. Asia Pacific Journal of Marketing and Logistics, 20(2), 174-189. 
IBT JOURNAL OF BUSINESS STUDIES (IBT-JBS) Volume 16 Issue 1, 2020

Chin, W. W. (1998). The partial least squares approach to structural equation modeling. Modern Methods for Business Research, 295(2), 295-336.

Claridge, T. (2020). Current definitions of social capital. Retrieved from https:// www.socialcapitalresearch.com/current-definitions-of-social-capital/

Damanpour, F., Walker, R.M., \& Avellaneda, C.N. (2009). Combinative effects of innovation types and organizational performance: A longitudinal study of service organizations. Journal of Management Studies, 46(4), 650-675.

Darroch, J. (2005). Knowledge management, innovation and firm performance. Journal of Knowledge Management, 9(3), 101-115.

Dodokh, A., \& Al-Maaitah, M. A. (2019) Impact of social media usage on organizational performance in the Jordanian dead sea cosmetic sector. European Journal of Business and Management, 11(2), 75-91.

Ellison, N.B., Steinfield, C., \& Lampe, C. (2007). The benefits of Facebook "friends:" Social capital and college students' use of online social network sites. Journal of Computer $\square$ Mediated Communication, 12(4), 1143-1168.

Fatoki, O.O. (2011). The impact of human, social and financial capital on the performance of small and medium-sized enterprises (SMEs) in South Africa. Journal of Social Sciences, 29(3), 193-204.

Felício, J.A., Couto, E., \& Caiado, J. (2014). Human capital, social capital and organizational performance. Management Decision, 52(2), 350-364.

Fernandez, I. B., \& Sabherwal, R. (2010). Knowledge management systems and processes. US: ME Sharpe.

Fornell, C., \& Larcker, D.F. (1981). Evaluating structural equation models with unobservable variables and measurement error. Journal of Marketing Research, $18(1), 39-50$.

Fu, Q. (2004). Trust, social capital, and organizational effectiveness. Blacksburg, VA.

Garson, D. (2016). Partial least squares: Regression and Structure Equation Models. USA: Statistical Publishing Associates.

Gomes, J., \& Romão, M. J. B. (2019). Sustainable competitive advantage with the balanced scorecard approach. In Advanced methodologies and technologies in business operations and management (pp. 1415-1428). Pennsylvania: IGI Global.

Gurteen, D. (2012). Leading issues in social knowledge management. UK: Academic Conferences \& Publishing International.

Page | 207 
Hair, J.F., \& Babin, B. Money, A.H. \& Samouel, P. (2003) Essentials of business research methods. NJ: John Wiley \& Sons.

Han, S. H., Chae, C., \& Passmore, D. L. (2019). Social network analysis and social capital in human resource development research: A practical introduction to $\mathrm{R}$ use. Human Resource Development Quarterly, 30(2), 219-243.

Hanna, R., Rohm, A., \& Crittenden, V.L. (2011). We're all connected: The power of the social media ecosystem. Business Horizons, 54(3), 265-273.

Helms, R., Cranefield, J., \& van Reijsen, J. (2017). Social media and knowledge management: A perfect couple. In: R. Helms, J. Cranefield, \& J. van Reijsen (Eds.), Social knowledge management in action (pp.1-13). Cham: Springer.

Hemsley, J., \& Mason, R.M. (2013). Knowledge and knowledge management in the social media age. Journal of Organizational Computing and Electronic Commerce, 23(1-2), 138-167.

Henseler, J., Ringle, C.M., \& Sarstedt, M. (2012). Using partial least squares path modeling in international advertising research: Basic concepts and recent issues. In S. Okzaki (Ed.), Handbook of partial least squares: Concepts, methods and applications in marketing and related fields (pp. 252-276). Berlin: Springer.

Hu, L.-T., \& Bentler, P.M. (1998). Fit indices in covariance structure modeling: Sensitivity to under parameterized model misspecification. Psychological Methods, 3(4), 424-453.

Hurley, R.F., \& Hult, G.T.M. (1998). Innovation, market orientation, and organizational learning: An integration and empirical examination. The Journal of Marketing, 62(3) 42-54.

Hussain, I., Qurashi, A., Mujtaba, G., Waseem, M.A., \& Iqbal, Z. (2019). Knowledge management: a roadmap for innovation in SMEs' sector of Azad Jammu \& Kashmir. Journal of Global Entrepreneurship Research, 9(1), 9.

Jussila, J.J., Kärkkäinen, H., \& Leino, M. (2012). Learning from and with customers with social media: A model for social customer. International Journal of Management, Knowledge and Learning, 1(1), 5-25.

Kazmi, S. H. (2012, September 3). Domestic appliances industry. Pakistan and Gulf Economist. Retrieved from http://www.pakistaneconomist.com/database2/ cover/c2012-163.php (accessed on October, 31, 2017).

Khaniki, H. (2011). Cyber space and social media: Implications and applications. Scientific Researching Journal of Informational Community,1(1), 71-96.

Kumar, V., \& Bhagwat, Y. (2010). Listen to the customer. Marketing Research, 22(2), 14-19. 
IBT JOURNAL OF BUSINESS STUDIES (IBT-JBS) Volume 16 Issue 1, 2020

Kwok, L., \& Yu, B. (2013). Spreading social media messages on Facebook. An analysis of restaurant business-to-consumer communications. Cornell Hospitality Quarterly, 54(1), 84-94.

Lee, E. (2013). Impact of social media on consumer behaviour. (Bachelor thesis). Turkish University of Applied Sciences, Turkey.

Lin, N., Ensel, W.M., \& Vaughn, J.C. (1981). Social resources and strength of ties: Structural factors in occupational status attainment. American Sociological Review, 46(4), 393-405.

Mangold, W.G., \& Faulds, D.J. (2009). Social media: The new hybrid element of the promotion mix. Business Horizons, 52(4), 357-365.

Mehmood, K.K., Sonia, F., \& Umar, A. (2016). Impact of organic structure on competitive performance of pharmaceutical companies in Pakistan: Study of mediating roles. Pakistan Journal of Social Sciences, 36(2), 821-834.

Mohammad, M.M., \& Roozbeh, H. (2014). Knowledge management reliability and its impact on organizational performance: An empirical study. Program, 48(2), 102-126.

Monavvarian, A., Asgari, N., Akhavan, P., \& Ashena, M. (2013). Developing social capital for facilitating knowledge management practices. International Journal of Social Economics, 40(9), 826-844.

Ndesaulwa, A.P., \& Kikula, J. (2017). The impact of innovation on performance of small and medium enterprises (SMEs) in Tanzania: A review of empirical evidence. Journal of Business and Management Sciences, 4(1), 1-6.

Ode, E., \& Ayavoo, R. (2020). The mediating role of knowledge application in the relationship between knowledge management practices and firm innovation. Journal of Innovation \& Knowledge, 5(3), 210-218.

Penrose, E.T. (1959). The theory of the growth of the firm. UK: Oxford University Press.

Pentina, I., Koh, A.C., \& Le, T.T. (2012). Adoption of social networks marketing by SMEs: Exploring the role of social influences and experience in technology acceptance. International Journal of Internet Marketing and Advertising, 7(1), $65-82$.

Rodriguez, M., Peterson, R.M., \& Ajjan, H. (2015) CRM/Social Media Technology: Impact on Customer Orientation Process and Organizational Sales Performance. In K. Kubacki (Ed.) Ideas in marketing: Finding the new and polishing the old (pp. 636-638). Cham: Springer.

Rogers, E.M. (2003). The diffusion of innovations model. NY: The Free Press.

Page $\mid 209$ 
IBT JOURNAL OF BUSINESS STUDIES (IBT-JBS) Volume 16 Issue 1, 2020

Sabatini, F. (2006). The empirics of social capital and economic development: A critical perspective. FEEM Working Paper (No. 15.2006). Available at SSRN: https://ssrn.com/abstract $=879712$ (accessed on November 15, 2019)

Schiuma, G. (2009). The managerial foundations of knowledge assets dynamics. Knowledge Management Research \& Practice, 7(4), 290-299.

Schiuma, G., De Pablos, P.O., \& Spender, J.C. (2007). Foreword: Intellectual capital and company's value creation dynamics. International Journal of Learning and Intellectual Capital, 4(4), 331-341.

Schiuma, G., Lerro, A., \& Sanitate, D. (2008). The intellectual capital dimensions of Ducati's turnaround: Exploring knowledge assets grounding a change management program. International Journal of Innovation Management, 12(02), 161-193.

Shuai, J.J., \& Wu, W.W. (2011). Evaluating the influence of E-marketing on hotel performance by DEA and grey entropy. Expert Systems with Applications, 38(7), 8763-8769.

Standing, C., \& Kiniti, S. (2011). How can organizations use wikis for innovation? Technovation, 31(7), 287-295.

Subohi, A. (2015, April 6). Brisk sales of appliances. Dawn. Retrieved from https:// www.dawn.com/news/1174131 (accessed on October, 31, 2017).

Taherparvar, N., Esmaeilpour, R., \& Dostar, M. (2014). Customer knowledge management, innovation capability and business performance: A case study of the banking industry. Journal of Knowledge Management, 18(3), 591-610.

Vuori, V., \& Okkonen, J. (2012). Refining information and knowledge by social media applications: Adding value by insight. Vine, 42(1), 117-128.

Wu, C.W. (2016). The performance impact of social media in the chain store industry. Journal of Business Research, 69(11), 5310-5316.

Yi, M.Y., \& Davis, F.D. (2003). Developing and validating an observational learning model of computer software training and skill acquisition. Information Systems Research, 14(2), 146-169.

Young, C.J. (2016). Knowledge management and innovation on firm performance of United States ship repair (Doctoral dissertation). Walden University, United States.

Zhao, S. (2006). Do Internet users have more social ties? A call for differentiated analyses of Internet use. Journal of Computer $\square$ Mediated Communication, 11(3), 844-862. 